Jensen, S. B. 1968: Field work in the Frederikshåb area. Rapp. Grønlands geol. Unders. 15, 40-44.

Jensen, S. B. 1969: Field work in the Frederikshåb district. Rapp. Grønlands geol. Unders. 19, 33-35.

Kalsbeek, F. \& Myers, J. S. 1973: The geology of the Fiskenæsset region. Rapp. Grønlands geol. Unders. 51, 5-18.

Kalsbeek, F. \& Taylor, P. N. 1985: Age and origin of early Proterozoic dolerite dykes in South-West Greenland. Contrib. Mineral. Petrol. 89, 307-316.

Rivalenti, G. 1975: Chemistry and differentiation of mafic dykes in an area near Fiskenæsset, West Greenland. Can. J. Earth Sci. 12, 721-730.

R. P. H. \& D. J. H.,

Department of Geology,

Portsmouth Polytechnic,

Burnaby Road,

Portsmouth, PO1 3QL,

U.K.
C. R. L.F, Department of Geol. and Phys. Sci., Oxford Polytechnic, Headington, Oxford $O X 3 O B P$ U.K.

\title{
Reconnaissance for noble and base metal mineralisation within the Precambrian supracrustal sequences in the Ivigtut-Kobberminebugt region, South-West Greenland
}

\author{
K. Secher and P. Kalvig
}

The field programme in the Ivigtut-Kobberminebugt region is a continuation of the investigation of gold occurrences in the Tartoq Group greenstones, just north of the present area (Appel \& Secher, 1984; Appel, 1984). The region was mapped by GGU in the late 1950s and early 1960s (Henriksen, 1969; Berthelsen \& Henriksen 1975; Harry \& Pulvertaft, 1963). The Tartoq and the Ketilidian supracrustal belts were described (Allaart, 1976; Bridgwater et al., 1976); they form regional curved structures around the Arsuk Basin. The major part of the supracrustal sequences south of the Tartoq Group units is expected to be of Ketilidian (Proterozoic) age and deformation. However, some layers in the Nunarssuit peninsula in the southernmost part of the region are undated and might be older (Bridgwater et al., 1973; Appel \& Secher, 1984).

The investigation was focussed on the supracrustal sequence between Arsuk Fjord and Nunarssuit (fig. 1), with special emphasis on the areas neighbouring the known gold showings at Josva Mine (worked 1910-15) where discrete grains of electrum and gold in the bornite ore were reported by Harry \& Oen (1964). In the Kinâlik peninsula a skarn boulder with a few grains of gold included in chalcopyrite has been reported by Kryolitselskabet $\emptyset$ resund A/S (Nielsen, 1976).

The work was based on reconnaissance rock sampling of lithologies and mineral showings within the supracrustal sequences, with particular attention given to transitions between sedimentary and volcanic suites and to structural breaks in order to locate potential sources of noble metals. 


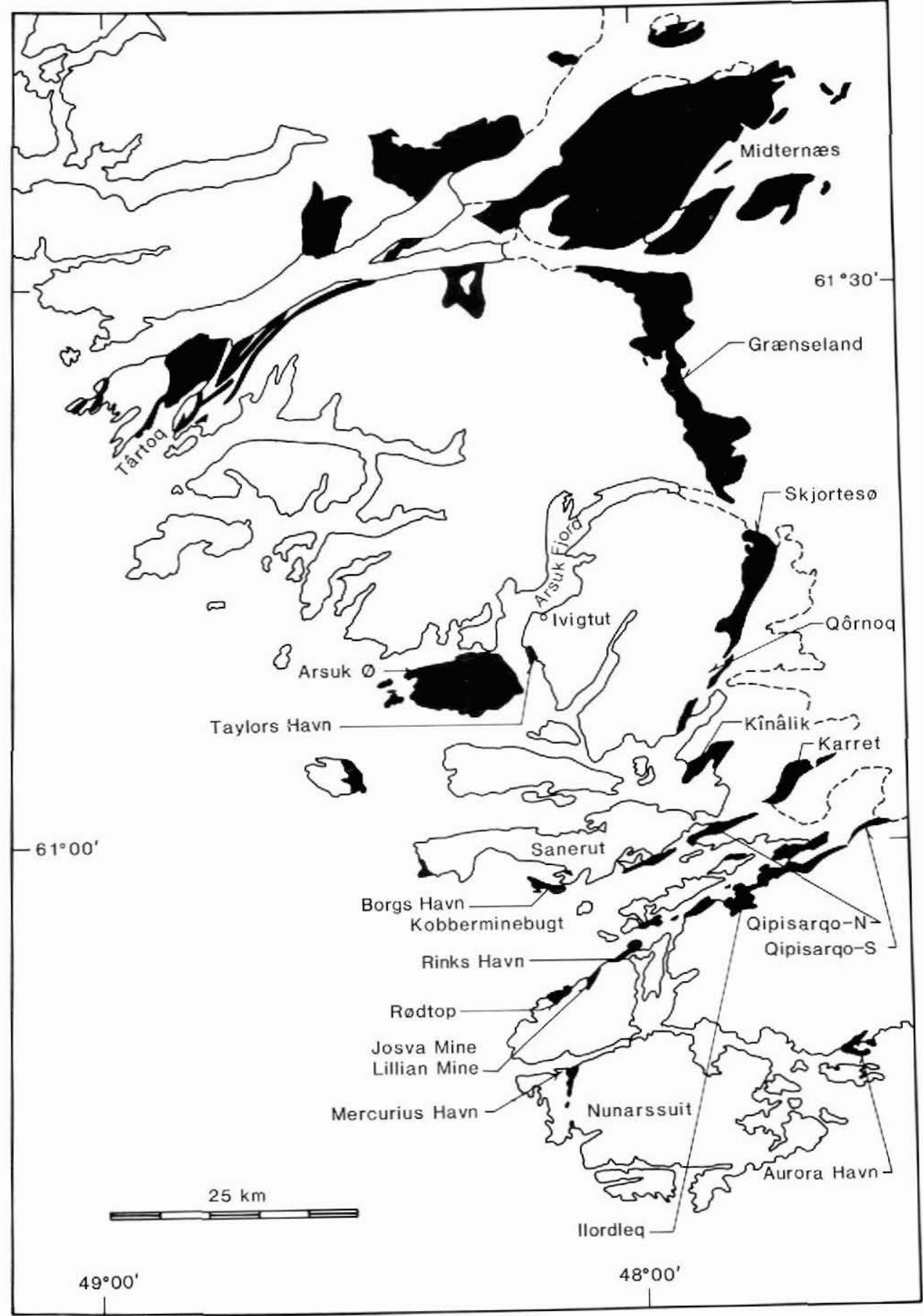

Fig. 1. Major sulphide localities in the Precambrian supracrustal sequences (block) between Tàrtoq and Kobberminebugt. 
The exposure was fair to good except in the south-eastern corner of the region adjacent to the ice margin where difficulties were met due to dense vegetation cover in the lowland areas. A collection of heavy mineral concentrates and subaquatic moss was made from the river system to obtain additional data for detection of mineralised areas.

\section{Regional geology}

Within the Ivigtut area the major geological features are gneiss complexes belonging to the Archaean shield, overlain by supracrustal sequences forming greenstone belts (Allaart, 1976). The Archaean greenstone belt known as the Tartoq Group (Higgins \& Bondesen, 1966) borders the area to the north. It is a predominantly volcanic succession with frequent intercalations of sedimentary rocks, deformed and metamorphosed in the upper greenschist facies. In the southern part of the area the Ilordleq Group, a greenschist sequence of unknown age and uncertain but pre-Ketilidian stratigraphic position (Bridgwater et al., 1973), covers the southern shore of the Kobberminebugt (Harry \& Oen, 1964; Ghisler, 1968). The Ilordleq Group includes intermediate and basic volcanic rocks with intercalated sedimentary material (black shale, pelite, greywacke and calcareous units) and pyroclastic material, metamorphosed in upper greenschist facies (Watterson, 1965; Allaart, 1976).

The eastern part of the Ivigtut area is covered by the Ketilidian supracrustal belt (estimated thickness of the order of $5000 \mathrm{~m}$ ) which comprises the Vallen and the Sortis Group (not considered in the present study), followed by the youngest sequence, the predominantly sedimentary Qipisarqo Group (Bridgwater et al., 1973). The Ketilidian supracrustal sequences are characterised by regional metamorphism increasing southward and ranging from low greenschist facies in the north to amphibolite facies in the Qipisarqo - Borgs Havn area (Escher \& Watt, 1976). The supracrustals are more or less continuous from Arsuk Fjord to Sánerut in the southernmost exposure. However, fjords dissect the area, thus making exact correlation from area to area difficult. Approaching Sánerut island from the north and east an increasing amount of cutting pegmatite and granite material is observed, breaking up the succession into isolated fragments, which makes correlation uncertain (Bridgwater et al., 1973).

The basement and the supracrustal rocks of the Nunarssuit peninsula are cut by late Ketilidian granites and Gardar alkaline intrusions. A sequence of xenoliths of basic metavolcanic rocks is preserved within the main Nunarssuit intrusions (Helene granite and Nunarssuit syenite). The age of these amphibolite facies metamorphosed xenoliths is unknown, although they are expected to be part of the Ilordleq Group (Harry \& Pulvertaft, 1963). It is possible that they might be of Gardar age (Harry \& Pulvertaft, 1963; J. G. Larsen, personal communication, 1986).

\section{Lithology and structure}

The area investigated includes a series of metasedimentary and metavolcanic supracrustal rocks. The metaconglomerate is composed of pebbles of felsic composition in a green, finegrained quartzitic-greywacke matrix. The conglomerate is apparently overlain by metasediments and (rarely) by metavolcanics. Mica schist is the most common supracrustal rock within the area. The schist varies from dark, fine-grained phyllitic slate to medium-grained, 
grey-brown, biotite-almandine-staurolite schist. The schist units are interlayered with quartzite, greywacke, arkoses and marble \pm dolomite horizons. These horizons vary from $0.1-50$ $\mathrm{m}$ in thickness and can be traced along strike from a few metres to considerable distances. Fuchsite horizons have been observed within the quartzite layers.

The metavolcanics of the area include tuffitic/rhyolitic rocks as well as basic metavolcanics; the latter group appears as fine- to medium-grained greenstones and greenschists with variable content of chlorite, mica, epidote, actinolite, albite and quartz. Only in the Ilordleq Group (e.g. in the area of Rinks Havn and the Josva Mine) were the metavolcanics interlayered with clastic metasediments together with acid metavolcanic rocks. Locally discordant quartz veins were observed, commonly in widths from $0.1-1 \mathrm{~m}$.

Basic, intermediate and acid dykes cut all the supracrustal units. They are generally rather narrow $(0.2-2 \mathrm{~m})$, but fairly consistent along strike. Pegmatites with muscovite, garnet and black tourmaline are widespread and may reach a width of $50 \mathrm{~m}$. Dykes and pegmatites usually strike in an $\mathrm{E}-\mathrm{W}$ direction.

The supracrustal sequences have been isoclinally folded and fractured on a small to a large scale. Tectonic breccia zones are observed frequently and the pebbles of the conglomerate are very much flattened tectonically indicating a high degree of regional deformation.

\section{Sulphide occurrences}

Sulphide mineralisation is found within the major volcanic and sedimentary lithologies. An important feature of all the sulphide occurrences is that they show a disseminated stratabound texture, often with location restricted to one rock unit. The sulphide mineralised layers are made up of anhedral sulphide grains which are generally less than $1 \mathrm{~mm}$. Locally the sulphide grains are united into stringers or even layers, typically in relation to strong folding and/or the appearance of discordant quartz veins. Only at one place (Borgs Havn) is there observed what can be termed 'ore tectonite', where an extreme sulphide enrichment is developed in the matrix.

The typical parageneses encountered in the supracrustals are simple and dominated by pyrite and chalcopyrite and are grouped as follows:

I pyrite \pm magnetite,

IIa pyrite-chalcopyrite,

IIb pyrrhotite-pyrite \pm chalcopyrite,

III chalcopyrite \pm galena,

IV bornite-chalcocite-chalcopyrite.

Group I occurs in schists sensu lato. Locally the rock can be termed greenschist; at one place including a banded iron formation (BIF) horizon with the magnetite-bearing part traceable for several kilometres along strike and up to $0.1 \mathrm{~m}$ wide.

Group IIa is dominated by greenschist and quartzite as host rocks. Late quartz veins are common and often mineralised when cutting the sulphide-enriched schist.

Group $I l b$ is found in micaceous and graphitic schists. The graphite content may reach $20 \%$ by volume. Pyrrhotite is the dominant sulphide mineral.

Group III occurs in marble horizons. Galena is rare, often with a disseminated texture, but is found locally in nodules. 
Group $I V$ is the only paragenesis apparently influenced by hydrothermal activity and is often accompanied by a suite of accessory minerals such as epidote and fluorite. Malachite is common as coatings on the copper-sulphide-carrying rocks, although many chalcopyrite showings do not exhibit supergene minerals. Stilbite has been recognised as a supergene product (Harry \& Oen, 1964), but only in the area around Josva Mine. However, stilbite is found at several localities all over the survey area as vein fillings in greenstone, and is likely to be explained as a sign of low temperature hydrothermal activity.

Gold has been found in groups III and IV (Kînâlik and Josva Mine, see above). Group III shows similarities in the field to group IIa which is fairly common, thus indicating a reasonable potential for the existence of gold (and silver) accumulations in some of the more widespread lithologies.

From the geochemical map (Armour-Brown et al., 1982) the distribution of selected elements in stream sediments similarly indicates the possibility of finding copper in parts of the surveyed area.

No visible gold has been observed in the pan concentrate. This is probably explained by the working method which aimed at collecting the maximum amount of material for mineralogical laboratory investigation.

Carbonaceous and arsenopyritic horizons as found within the Tartoq Group were not observed. No other field evidence was found suitable for correlation between the Tartoq Group and supracrustals of unknown age within the surveyed area.

In Table 1 the distribution of the different types of mineralisation is shown. The status of the sulphide and noble metal occurrences in the localities are summarised below.

Skjortes $\phi$ (Arsuk Fjord). Massive sulphides within the dolomitic marble form lenticular bodies traceable for several metres along strike. The quartzite carries fuchsite in unmineralised layers. Quartz veins, carrying pyrite and chalcopyrite, cross-cutting the supracrustals are rather common.

Qôrnoq. Sulphides are scattered and only found in a few layers. The area, however, is interesting because of galena mineralisation within the marble, found locally together with chalcopyrite in calc-silicate nodules. Additionally concordant magnetite stringers are observed in mylonitised greenschist.

Kinâlik. The chalcopyrite is hosted in a sequence of marble-containing ultrabasic lenses and cut by quartz veins. All rock units are chalcopyrite-bearing.

Karret (east of Qôrnoq Fjord). Mica schist layers up to $50 \mathrm{~m}$ wide in gneiss are very rusty due to large amounts of weathered pyrite and pyrrhotite, locally with sulphide contents up to $25 \%$ by volume.

Qipisarqo-North. Chalcopyrite is found at the flanks of what is supposed to represent a narrow sequence of BIF. The Qipisarqo conglomerate is found locally to contain chalcopyrite disseminated in the green matrix. Additionally a few grains of chalcopyrite are observed in the cherty pebbles, thus supporting the hypothesis that it belongs to the youngest Ketilidian unit, with a reworked older copper content.

Qipisarqo - South. The dominating sulphide-bearing rock type is a black graphitic schist which is only exposed to a limited extent. The content of mixed sulphides of paragenesis IIb may reach $20 \%$ by volume. Rocks with metagabbroic appearance and even larger sulphide contents are observed in floats.

Borgs Havn. The sulphides in this area deserve special attention because of the sulphide content and the size of the mineralised layers. Combined $\mathrm{Cu}-\mathrm{Fe}$ sulphides of 5-10 per cent 
Table 1. Sulphide occurrences in the Ivigtut-Kobberminebugt region

\begin{tabular}{|c|c|c|c|c|c|c|}
\hline Locality & $\begin{array}{l}\text { Ore } \\
\text { minerals }\end{array}$ & $\begin{array}{c}\text { Para- } \\
\text { genesis }\end{array}$ & Host rock & $\begin{array}{l}\text { Texture of } \\
\text { ore minerals }\end{array}$ & $\begin{array}{l}\text { Sulphide } \\
\text { vol. } \%\end{array}$ & $\begin{array}{c}\text { Thickness } \\
\mathrm{m}\end{array}$ \\
\hline Skjortesø & $p y, c p$ & II & Marble & dissem, massive & $5-50$ & A \\
\hline Skjortes $\emptyset$ & py & I & Phyrite schist & dissem & $5-10$ & B \\
\hline Skjortes $\varnothing$ & $\mathrm{py}, \mathrm{cp}$ & II & Quartzite & dissem & $5-15$ & A \\
\hline Skjortes $\emptyset$ & $\mathrm{py}, \mathrm{cp}$ & II & Q-vein & patchy & $1-5$ & A \\
\hline Qôrnoq & $\mathrm{cp}, \mathrm{ga}$ & III & Marble & patchy & $<1$ & A \\
\hline Qôrnoq & py, mg & I & Schist & stringer & $<1$ & A \\
\hline Qôrnoq & py & I & Mica schist & dissem & $1-5$ & $\mathrm{~B}$ \\
\hline Kînâlik & $\mathfrak{c p}$ & III & Marble & dissem & $1-5$ & A \\
\hline Kînâlik & $c p$ & II & Q-vein & patchy & $<1$ & A \\
\hline Karret & py, ph & IIa & Mica schist & dissem, massive & $5-25$ & $\mathbf{B}$ \\
\hline Qipisarqo-N & $\mathrm{cp}$ & II & Conglomerate & dissem & $1-5$ & $\mathrm{~B}$ \\
\hline Qipisarqo-N & py & I & Quartzite & dissem, stringer & $1-5$ & B \\
\hline Qipisarqo-N & py, mg & I & Greenschist & dissem & $1-5$ & A \\
\hline Qipisarqo-S & $\mathrm{cp}, \mathrm{py}, \mathrm{ph}$ & IIa & Black schist & dissem, massive & $10-20$ & B \\
\hline Borgs Havn & $\mathrm{cp}, \mathrm{py}$ & IIN & 'Tectonite' & massive & $10-50$ & B \\
\hline Borgs Havn & $\mathrm{cp}, \mathrm{py}$ & II & Greenschist & dissem, massive & $5-15$ & B \\
\hline Borgs Havn & py & I & Quartzite & dissem & $1-10$ & B \\
\hline Ilordleq & $\mathrm{cp}, \mathrm{py}$ & II & Greenschist & dissem & $<1$ & $\mathbf{A}$ \\
\hline Rinks Havn & $\mathrm{cp}$, bo & IV & Mica schist & stringer, dissem & $5-10$ & A \\
\hline Josva Mine & $\mathrm{cp}$, bo, $\mathrm{mg}$ & II - IV & Greenschist & dissem, stringer & $1-5$ & B \\
\hline Josva Mine & $\mathrm{cp}, \mathrm{bo}, \mathrm{co}$ & IV & Q-vein & patchy & $5-20$ & B \\
\hline Lillian Mine & $\mathrm{cp}, \mathrm{bo}, \mathrm{co}$ & IV & Q-vein & patchy & $<1$ & A \\
\hline Rødtop & $\mathrm{cp}$, co & IV & Q-vein & patchy & $1-5$ & B \\
\hline Rødtop & py & I & Rhyolite & dissem & $<1$ & A \\
\hline Mercurius Havn & py, py & II & Greenstone & dissem & $1-5$ & A \\
\hline Aurora Havn & py & I & Metabasite & dissem & $1-5$ & A \\
\hline Taylors Havn & py & I & Graphite schist & dissem & $5-10$ & B \\
\hline
\end{tabular}

$\begin{array}{ll}\text { 1. } & \text { Ore minerals } \\ \text { 2. } & \text { Paragenesis } \\ \text { 3. } & \text { Host rock } \\ & \\ \text { py } & \text { pyrite } \\ \text { cp } & \text { chalcopyrite } \\ \text { ga } & \text { galena } \\ \text { ph } & \text { pyrrhotite }\end{array}$

4. Texture of the ore minerals
5. Estimated sulphide vol. percent
6. Thickness of mineralised sequence:
$\mathrm{A}=\langle\mathrm{lm}, \mathrm{B}=>1 \mathrm{~m}$
$\mathrm{mg}$ magnetite
bo bornite
co chalcocite

by volume can be traced for several 100 metres along strike in widths of $0.5-5 \mathrm{~m}$. The 'ore tectonite' mentioned above is remarkable because of a matrix with up to $50 \%$ pyrite and chalcopyrite. Ilordleq-Rinks Havn. This area deserves attention because of the frequent appearance of chalcopyrite, although the grains are small and very scattered. At Rinks Havn a $1 \mathrm{~m}$ layer of mica schist with quartz veins shows disseminated type and stringers of bornite.

Josva Mine - Rødtop. Bornite is found disseminated in greenstone, as well as in quartz veins, giving rise to this well known copper deposit. Chalcocite is an accessory but also occurs alone in quartz veins, up to $2 \mathrm{~m}$ wide. Rhyolitic layers contain disseminated pyrite in accessory amounts.

Mercurius Havn - Aurora Havn. Sulphides are scattered and disseminated when observed. They are located in metabasic rocks often within epidotised nodules. 
Taylors Havn. Imposing layers of graphite schist contain locally moderate amounts of pyrite, which might by comparable to the Skjortes $\emptyset$ rocks.

\section{Preliminary conclusions}

The potential for noble metals is fair to good at several localities within the supracrustal sequence based on the paragenetic knowledge of recorded gold-carrying mineralisation.

Observed sulphide minerals are predominantly stratabound in basic metavolcanics, commonly disseminated in a syngenetic manner, and presumably originated in relation to primary volcanic flows.

Base metal sulphides were reorganised during deformation and hydrothermal activity giving rise to possible mineral concentrations.

The Ilordleq Group, from a field exploration point of view, is not a continuation of the Ketilidian supracrustal belt.

Important prospecting targets for noble and base metal mineralisation are indicated within the Qipisarqo Group and within the Ilordleq Group. Late quartz-veins, especially in the Skjortes $\emptyset$ area might also be prospective carriers of munedisator.

\section{References}

Allaart, J. H. 1976: Ketilidian mobile belt in south Greenland. In Escher, A. \& Watt, W. S. (edit.) Geology of Greenland, 121-151. Copenhagen: Geol. Surv. Greenland.

Appel, P. W. U. 1984: An iron-formation in the Precambrian Tartoq Group, South-West Greenland. Rapp. Grønlands geol. Unders. 120, 74-78.

Appel, P. W. U. \& Secher, K. 1984: On a gold mineralization in the Precambrian Tartoq Group, SouthWest Greenland. J. geol. Soc. Lond., 141, 273-278.

Armour-Brown, A., Tukiainen, T. \& Wallin, B. 1982: The South Greenland uranium exploration programme: Final report. Unpubl. intern. GGU. rep.

Berthelsen, A. \& Henriksen, N. 1975: Geological map of Greenland 1:100 000. Ivigtut 61 V.1 Syd; Descriptive text. Geol. Surv. Greenland, $169 \mathrm{pp}$.

Bridgwater, D., Escher, A. \& Watterson, J. 1973: Dyke swarms and the persistence of major geological boundaries in Greenland. In Park, R. G. \& Tarney, J. (edit.) The Early Precambrian of Scotland and related rocks of Greenland, 137-142. Univ. Keele.

Bridgwater, D., Keto, L., McGregor, V. R. \& Myers, J. S. 1976: Archaean gneiss complex of Greenland. In Escher, A. \& Watt, W. S. (edit.) Geology of Greenland, 19-75.

Escher, A. \& Watt, W. S. (edit.) 1976: Geology of Greenland. Copenhagen: Geol Surv. Greenland, 603 pp.

Ghisler, M. 1968: The geological setting and mineralizations west of Lilian mine, South Greenland. Rapp. Grønlands geol. Unders. 16, $53 \mathrm{pp}$.

Harry, W. T. \& Oen, I. S. 1964: The pre-Cambrian basement of Alangorssuaq South Greenland and its copper mineralization at Josvaminen. Bull. Grønlands geol. Unders. 47 (also Meddr Grønland 179 (1)), $72 \mathrm{pp}$.

Harry, W. T. \& Pulvertaft, T. C. R. 1963: The Nunarssuit intrusive complex, South Greenland. Bull. Grønlands geol. Unders. 36 (also Meddr Grønland 169(1)), 136 pp.

Henriksen, N. 1969: Boundary relations between Precambrian fold belts in the Ivigtut area, Southwest Greenland. Spec. Pap. geol. Ass. Can. 5, 143-154.

Higgins, A. K. \& Bondesen, E. 1966: Supracrustals of pre-Ketilidian age (the Tartoq Group) and their 
relationships with Ketilidian supracrustals in the Ivigtut region, South-West Greenland. Rapp. Grønlands geol. Unders. 8, 21 pp.

Nielsen, B. L. 1976: Economic minerals. In Escher, A. \& Watt, W. S. (edit.) Geology of Greenland, 460-487. Copenhagen: Geol. Surv. Greenland.

Watterson, J. 1965: Plutonic development of the Ilordleq area, South Greenland. I: Chronology, and the occurrence and recognition of metamorphosed basic dykes. Bull. Grønlands geol. Unders. 51, 147 pp.

\title{
Regional geological investigations in the Ammassalik district, South-East Greenland
}

\author{
Feiko Kalsbeek and Troels F. D. Nielsen
}

One of GGU's main expeditions in 1986 took place in July and August in the Ammassalik (Angmagssalik) district of South-East Greenland between $64^{\circ}$ and $67^{\circ} \mathrm{N}$ (fig. 1). Until this summer the geology of this region was known only superficially, mainly from reconnaissance by Wager (1934), from local mapping projects by the University of Birmingham in the sixties and early seventies (Wright et al., 1973) and from coastal reconnaissance carried out by GGU under the direction of D. Bridgwater, mainly in the seventies (e.g. Bridgwater \& Gormsen, 1968; Bridgwater et al., 1977; Bridgwater \& Myers, 1979). The present work had two major aims: to provide regional data for the preparation of the 1:500 000 map sheet 14 and to obtain an impression of the area's economic mineral resources. Much of the summer's work was based on helicopter support which made it possible to study large inland areas that had not been visited previously.

\section{Organisation}

The operations in the Ammassalik district were performed in close co-operation with the Geodætisk Institut (GI) which carried out surveying and gravimetric measurements in the region between Ammassalik and Scoresby Sund (around $70^{\circ} \mathrm{N}$ ). Because of this co-operation it was possible for about three weeks to have GGU parties in the field in the Kangerdlugssuaq area and farther north along Blosseville Kyst. Some aspects of this work are reported upon by Brooks et al. (this report).

Two helicopters were chartered for the operation from Uni-fly, Denmark, through Greenlandair Charter A/S: a McDonald-Douglas (Hughes) $500 \mathrm{E}$ (chartered by GGU), and an Aerospatiale Ecureuil 350 B1 (chartered by GI). The use of the helicopters was shared by GGU and GI. The helicopters were transported between Ammassalik and Ålborg, Denmark, by KNI, the Greenlandic trading organisation.

The work in the Ammassalik region was carried out from two coastal base camps, a main camp erected and manned by GGU a few kilometres north of Ammassalik (c. $\left.65^{\circ} 40^{\prime} \mathrm{N}\right)$ and, for a few weeks at the beginning of the season, from a camp set up and organised by GI at Nigertuluk (c. $66^{\circ} 22^{\prime} \mathrm{N}$ ). The Ammassalik base staff consisted of Jørgen Lau and Palle Bay 